\title{
Assessment of Undiscovered Oil and Gas Resources in the Central North Slope of Alaska, 2020
}

Using a geology-based assessment methodology, the U.S. Geological Survey estimated undiscovered, technically recoverable mean resources of 3.6 billion barrels of oil and 8.9 trillion cubic feet of natural gas (associated and nonassociated) in conventional accumulations in Mississippian through Paleogene strata in the central North Slope of Alaska.

\section{Introduction}

The U.S. Geological Survey (USGS) quantitatively assessed the potential for undiscovered, technically recoverable oil and gas resources in conventional accumulations in the Arctic Alaska Composite Total Petroleum System in the central North Slope of Alaska, including adjacent State waters (fig. 1). The central North Slope lies north of the Brooks Range, east of the National Petroleum Reserve-Alaska, and west of the Arctic National Wildlife Refuge. The assessment area hosts most of the producing oil and gas fields in Arctic Alaska, from which more than 18 billion barrels of oil have been produced. The central North Slope is traversed by The Trans-Alaska Pipeline, and it remains lightly explored outside the area of existing production.

Oil- and gas-prospective strata of the central North Slope historically have been divided into three main tectonostratigraphic sequences: (1) Mississippian to Triassic Ellesmerian Sequence, (2) Jurassic to Lower Cretaceous (Hauterivian) Beaufortian Sequence, and (3) Lower Cretaceous (post-Hauterivian) to Tertiary Brookian Sequence (Houseknecht, 2019a). Much of the historical oil exploration in the central North Slope has focused on the Ellesmerian Sequence, which includes the main oil reservoirs at the supergiant Prudhoe Bay Field (the largest conventional oil field in North America), and the Beaufortian Sequence, which includes the main reservoirs at the Kuparuk River Field (the second largest oil field in Alaska). Those huge oil fields and most of the smaller oil accumulations discovered in the past half

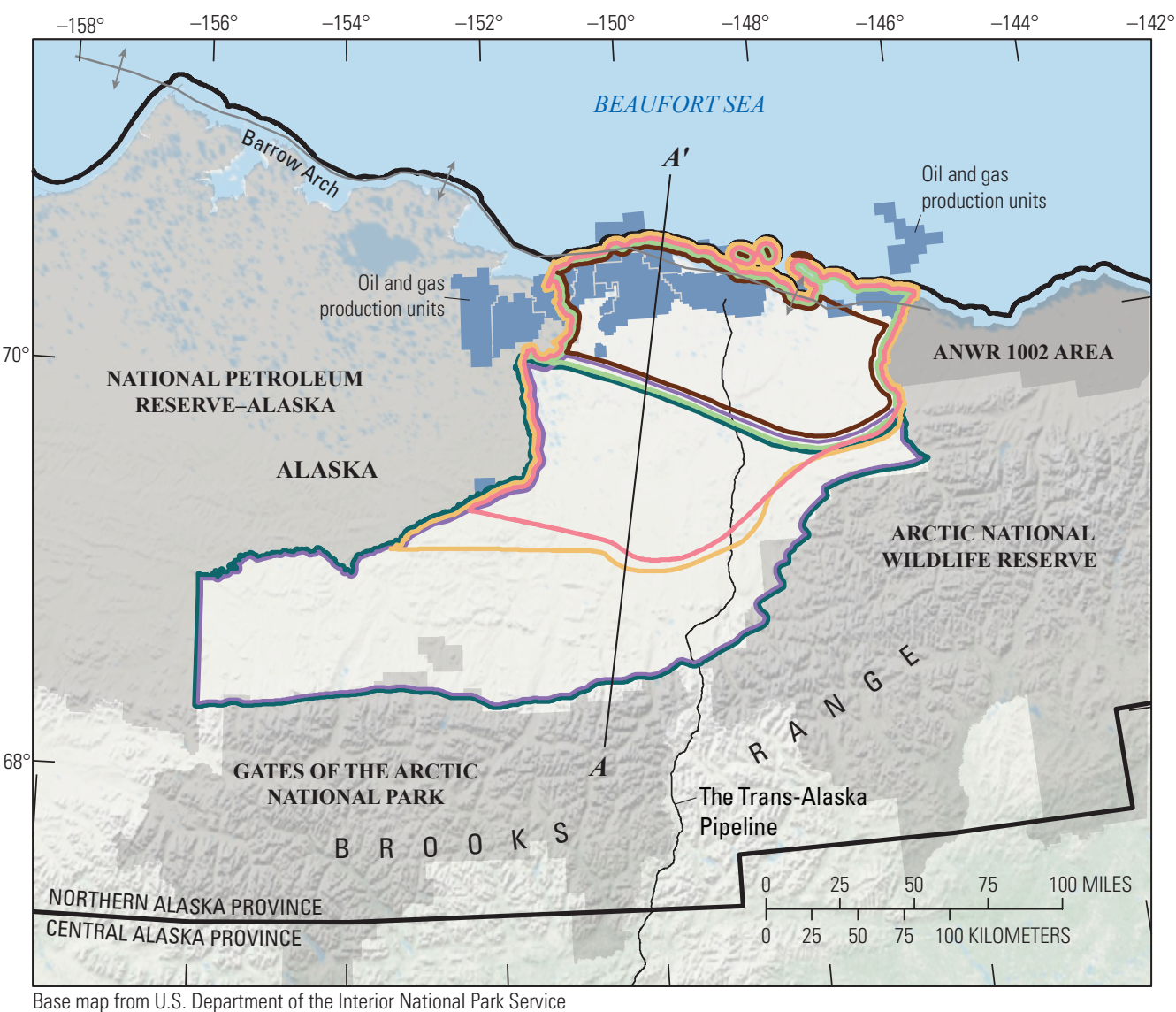

\section{EXPLANATION}

Ellesmerian Strata North AU Ellesmerian Strata South AU Beaufortian Strata North AU Beaufortian Strata South AU Brookian Topset AU Brookian Foreset-Bottomset AU Province boundary (part)

Anticlinorium-Arrows show rollover from south to north, dips north, dips south. Line is accurately defined

$A-A^{\prime}$ Line of section

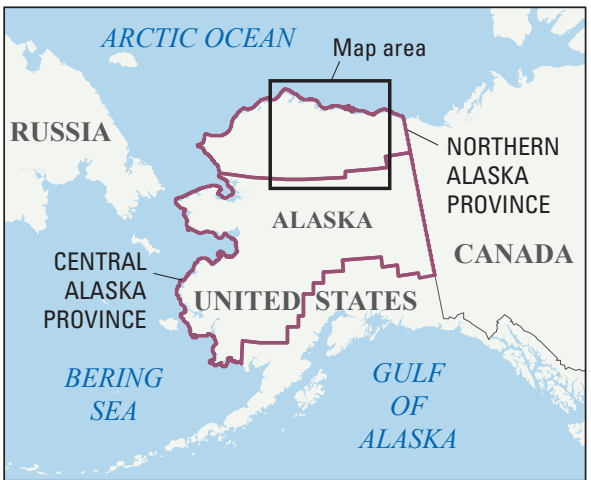

Figure 1. Map showing the location of six assessment units (AUs) in the central North Slope of Alaska, Federal land boundaries (including the Arctic National Wildlife Refuge [ANWR] 1002 area), oil and gas units (existing fields and areas approved as fields but not yet producing), and The Trans-Alaska Pipeline. Adjacent lines illustrate a shared boundary at the outermost line. 
century lie along the Barrow Arch, a giant subsurface structure along the Arctic coast of the central North Slope (fig. 2).

More recently, significant oil discoveries in stratigraphic traps in the Beaufortian Sequence (for example, the Colville River [or Alpine] Field) have stimulated exploration south of the Barrow Arch. This trend in exploration has resulted in significant (likely giant) oil discoveries between 2013 and 2017 at shallow (around 4,000 feet or 1,200 meters) depths in the Brookian Sequence (Houseknecht, 2019b). These latest discoveries have stimulated renewed leasing across the central North Slope, suggesting that the Brookian Sequence will be the main focus of exploration in coming years.

\section{Total Petroleum System and Assessment Units}

Rich, oil-prone source rocks are in the Ellesmerian, Beaufortian, and Brookian Sequences in various parts of the assessment area (Houseknecht, 2019a). Studies of oil geochemistry from producing oil fields indicate that certain oil accumulations were sourced mainly from one of those source rocks and that many oil accumulations represent mixtures of oil from two or more of those source rocks (for example, Wang and others, 2014). Since the spatial distribution of oil generated from each specific source rock is poorly known and mixing of oils from multiple source rocks occurred, we consider the central North Slope to be part of the Arctic Alaska Composite Total Petroleum System (Bird and Houseknecht, 2011).

Six assessment units (AUs) were defined in the Ellesmerian, Beaufortian, and Brookian Sequences, all of which contain known and potential reservoirs (Houseknecht, 2019a). Ellesmerian and Beaufortian strata are each divided into north and south AUs. The north AUs are mainly in the oil window (more oil accumulations than gas accumulations are anticipated), and potential traps include stratigraphic, unconformity, faultblock, and subtle fold geometries. The south AUs are mainly in the gas window (more gas than oil accumulations are anticipated), and potential traps include thrust-faulted and folded structures and stratigraphic geometries.

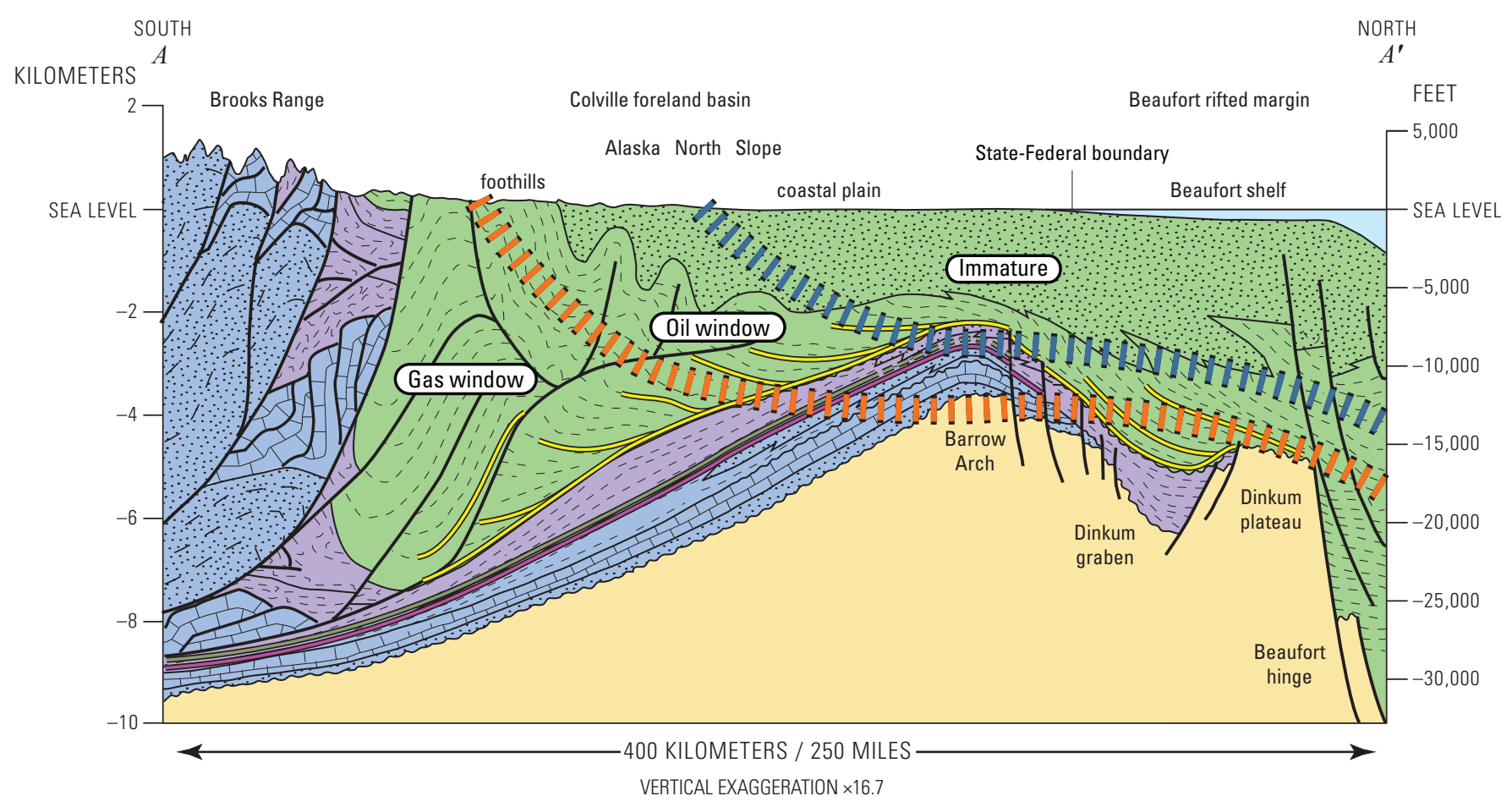

Stratigraphic sequences

Basement (pre-Mississippian)

Ellesmerian (Mississippian-Triassic)

Beaufortian (Jurassic-Cretaceous)

Brookian (Cretaceous-Tertiary)

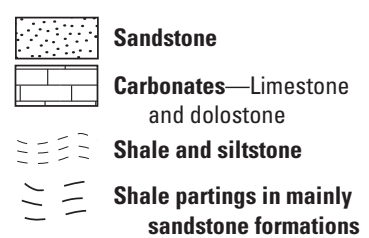

sandstone formations

\section{IIII}

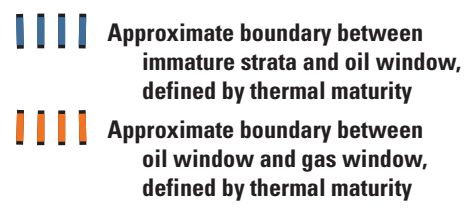

Figure 2. Cross section of the central North Slope showing generalized stratigraphic and structural relationships from the Brooks Range to the Beaufort Sea shelf edge (location shown in fig. 1). The stratigraphic positions of three main source rocks are shown schematically: the Shublik Formation near the top of the Ellesmerian Sequence, the Kingak Shale at the base of the Beaufortian Sequence, and the Brookian at the base of - and as tongues within — the Brookian Sequence. Source rocks are thermally immature above the segmentedblue line, in the thermally mature oil window between the segmented blue and orange lines, and in the thermally supramature gas window below and south of the orange line. Figure modified from Bird and Houseknecht (2011) and Houseknecht (2019a). 
Two AUs are defined in Brookian strata based on seismicreflection character. Brookian strata that display foreset and bottomset seismic facies include marine slope and deepwater deposits; Brookian strata that display topset seismic facies include shallow marine, shoreface, delta, and nonmarine deposits. Both Brookian AUs are mainly in the oil window, and potential traps include stratigraphic and structural geometries. Significantly, Brookian strata in the Torok (foreset-bottomset) and Nanushuk (topset) Formations in the central North Slope are excluded from this assessment because they were previously assessed (Houseknecht and others, 2017).

\section{Undiscovered Resources Summary}

Input data and results of the USGS quantitative assessment in the central North Slope of Alaska are shown in tables 1 and 2. The fully risked, estimated mean total resources for the central North Slope include 3,591 million barrels of oil (MMBO), or 3.6 billion barrels of oil, and 8,942 billion cubic feet of natural gas (BCFG, including both associated and nonassociated), or 8.9 trillion cubic feet of natural gas, and 67 million barrels of natural gas liquids in conventional reservoirs.

The largest undiscovered oil resources are assessed in the two Brookian AUs. The Brookian Topset AU is estimated to hold between 443 and 3,502 MMBO (F95-F5) with a mean of
1,573 MMBO. The Brookian Foreset-Bottomset AU is estimated to hold between 239 and 2,443 MMBO (F95-F5) with a mean of 975 MMBO. These estimates include large ranges of uncertainty, which reflect the immature stage of exploration for stratigraphic traps in Brookian strata. Assessed oil resources are smaller in the Beaufortian Strata North (ranging from 161 to 1,401 MMBO with a mean of $577 \mathrm{MMBO}$ ) and Ellesmerian Strata North (ranging from 91 to $869 \mathrm{MMBO}$ with a mean of $356 \mathrm{MMBO}$ ) AUs, a reflection of the mature stage of exploration and relatively small size of remaining untested targets in those strata. Assessed oil resources are significantly smaller in the Beaufortian Strata South (ranging from 0 to $174 \mathrm{MMBO}$ with a mean of $45 \mathrm{MMBO}$ ) and Ellesmerian Strata South (ranging from 16 to $216 \mathrm{MMBO}$ with a mean of $65 \mathrm{MMBO}$ ) AUs because most accumulations are expected to be nonassociated gas rather than oil.

The largest undiscovered gas resources are assessed in the Ellesmerian Strata South (total mean of 2,673 BCFG, including nonassociated and associated gas) and Beaufortian Strata South (total mean of $1,874 \mathrm{BCFG}$, including nonassociated and associated gas) AUs, mainly a reflection of the high thermal maturity of the southern parts of the central North Slope. These estimates are characterized by large ranges of uncertainty owing to exploration evidence that the southern area is gasprone and to the lack of historical drilling in the absence of a market for North Slope gas.

Table 1. Key input data for six conventional assessment units in the central North Slope of Alaska.

[AU, assessment unit; MMBO, million barrels of oil; BCFG, billion cubic feet of gas. Shading indicates not applicable]

\begin{tabular}{|c|c|c|c|c|c|c|c|c|}
\hline \multirow{2}{*}{$\begin{array}{c}\text { Assessment input data- } \\
\text { Conventional AUs }\end{array}$} & \multicolumn{4}{|c|}{ Ellesmerian Strata North AU } & \multicolumn{4}{|c|}{ Ellesmerian Strata South AU } \\
\hline & Minimum & Median & Maximum & Calculated mean & Minimum & Median & Maximum & Calculated mean \\
\hline Number of oil fields & 1 & 13 & 50 & 14.3 & 1 & 3 & 5 & 3.0 \\
\hline Number of gas fields & 1 & 2 & 12 & 2.3 & 1 & 22 & 80 & 24.0 \\
\hline Size of oil fields (MMBO) & 5 & 10 & 1,000 & 24.9 & 5 & 7 & 1,500 & 21.4 \\
\hline Size of gas fields (BCFG) & 30 & 60 & 8,000 & 168.2 & 30 & 42 & 6,000 & 107.8 \\
\hline AU probability & 1.0 & & & & 1.0 & & & \\
\hline \multirow{2}{*}{$\begin{array}{l}\text { Assessment input data- } \\
\text { Conventional AUs }\end{array}$} & \multicolumn{4}{|c|}{ Beaufortian Strata North AU } & \multicolumn{4}{|c|}{ Beaufortian Strata South AU } \\
\hline & Minimum & Median & Maximum & Calculated mean & Minimum & Median & Maximum & Calculated mean \\
\hline Number of oil fields & 1 & 22 & 70 & 23.6 & 1 & 3 & 20 & 3.6 \\
\hline Number of gas fields & 1 & 3 & 21 & 3.6 & 1 & 22 & 80 & 24.0 \\
\hline Size of oil fields (MMBO) & 5 & 8 & 1,500 & 24.5 & 5 & 7 & 1,000 & 18.0 \\
\hline Size of gas fields (BCFG) & 30 & 48 & 6,000 & 123.3 & 30 & 42 & 6,000 & 107.8 \\
\hline AU probability & 1.0 & & & & 0.7 & & & \\
\hline \multirow{2}{*}{$\begin{array}{c}\text { Assessment input data- } \\
\text { Conventional AUs }\end{array}$} & \multicolumn{4}{|c|}{ Brookian Topset AU } & \multicolumn{4}{|c|}{ Brookian Foreset-Bottomset AU } \\
\hline & Minimum & Median & Maximum & Calculated mean & Minimum & Median & Maximum & Calculated mean \\
\hline Number of oil fields & 1 & 32 & 115 & 34.8 & 1 & 24 & 83 & 26.0 \\
\hline Number of gas fields & 1 & 3 & 34 & 4.0 & 1 & 6 & 9 & 6.0 \\
\hline Size of oil fields (MMBO) & 5 & 13 & 2,500 & 45.1 & 5 & 10 & 2,500 & 37.5 \\
\hline Size of gas fields (BCFG) & 30 & 70 & 10,000 & 208.3 & 30 & 60 & 11,000 & 193.9 \\
\hline AU probability & 1.0 & & & & 1.0 & & & \\
\hline
\end{tabular}


Table 2. Results for six conventional assessment units in the central North Slope of Alaska.

[MMBO, million barrels of oil; BCFG, billion cubic feet of gas; NGL, natural gas liquids; MMBNGL, million barrels of natural gas liquids. Results shown are fully risked estimates. F95 represents a 95-percent chance of at least the amount tabulated; other fractiles are defined similarly. Shading indicates not applicable]

\begin{tabular}{|c|c|c|c|c|c|c|c|c|c|c|c|c|c|c|}
\hline \multirow{3}{*}{$\begin{array}{l}\text { Total petroleum system and } \\
\text { assessment units (AUs) }\end{array}$} & \multirow{3}{*}{$\begin{array}{c}\text { AU } \\
\text { prob- } \\
\text { ability }\end{array}$} & \multirow{3}{*}{$\begin{array}{c}\text { Accu- } \\
\text { mulation } \\
\text { type }\end{array}$} & \multicolumn{12}{|c|}{ Total undiscovered resources } \\
\hline & & & \multicolumn{4}{|c|}{ Oil (MMBO) } & \multicolumn{4}{|c|}{ Gas (BCFG) } & \multicolumn{4}{|c|}{ NGL (MMBNGL) } \\
\hline & & & F95 & F50 & F5 & Mean & F95 & F50 & F5 & Mean & F95 & F50 & F5 & Mean \\
\hline \multicolumn{15}{|c|}{ Arctic Alaska Composite Total Petroleum System } \\
\hline \multirow{2}{*}{ Ellesmerian Strata North AU } & \multirow{2}{*}{1.0} & Oil & 91 & 284 & 869 & 356 & 63 & 199 & 612 & 249 & 1 & 2 & 6 & 2 \\
\hline & & Gas & & & & & 40 & 185 & 1,392 & 393 & 0 & 1 & 10 & 3 \\
\hline \multirow{2}{*}{ Ellesmerian Strata South AU } & \multirow{2}{*}{1.0} & Oil & 16 & 32 & 216 & 65 & 23 & 48 & 324 & 98 & 0 & 0 & 3 & 1 \\
\hline & & Gas & & & & & 742 & 2,098 & 6,124 & 2,575 & 5 & 15 & 43 & 18 \\
\hline \multirow{2}{*}{ Beaufortian Strata North AU } & \multirow{2}{*}{1.0} & Oil & 161 & 463 & 1,401 & 577 & 113 & 324 & 985 & 404 & 1 & 3 & 9 & 4 \\
\hline & & Gas & & & & & 69 & 244 & 1,495 & 448 & 1 & 2 & 11 & 3 \\
\hline \multirow{2}{*}{ Beaufortian Strata South AU } & \multirow{2}{*}{0.7} & Oil & 0 & 21 & 174 & 45 & 0 & 32 & 262 & 68 & 0 & 0 & 2 & 1 \\
\hline & & Gas & & & & & 0 & 1,462 & 5,480 & 1,806 & 0 & 10 & 38 & 13 \\
\hline \multirow{2}{*}{ Brookian Topset AU } & \multirow{2}{*}{1.0} & Oil & 443 & 1,332 & 3,502 & 1,573 & 87 & 265 & 711 & 315 & 1 & 2 & 6 & 3 \\
\hline & & Gas & & & & & 76 & 405 & 3,036 & 824 & 1 & 3 & 21 & 6 \\
\hline \multirow{2}{*}{ Brookian Foreset-Bottomset AU } & \multirow{2}{*}{1.0} & Oil & 239 & 776 & 2,443 & 975 & 143 & 466 & 1,468 & 585 & 1 & 4 & 13 & 5 \\
\hline & & Gas & & & & & 280 & 745 & 3,584 & 1,177 & 2 & 5 & 25 & 8 \\
\hline $\begin{array}{l}\text { Total undiscovered conventional } \\
\text { resources }\end{array}$ & & & 950 & 2,908 & 8,605 & 3,591 & 1,636 & 6,473 & 25,473 & 8,942 & 13 & 47 & 187 & 67 \\
\hline
\end{tabular}

\section{References Cited}

Bird, K.J., and Houseknecht, D.W., 2011, Geology and petroleum potential of the Arctic Alaska petroleum province, chap. 32 of Spencer, A.M., Embry, A.F., Gautier, D.L., Stoupakova, A.V., and Sørensen, K., eds., Arctic petroleum geology: The Geological Society of London, Memoir 35, p. 485-499.

Houseknecht, D.W., 2019a, Evolution of the Arctic Alaska sedimentary basin, chap. 18 of Miall, A.D., ed., The sedimentary basins of the United States and Canada, second edition: Elsevier, p. 719-745.

Houseknecht, D.W., 2019b, Petroleum systems framework of significant new oil discoveries in a giant Cretaceous (Aptian-Cenomanian) clinothem in Arctic Alaska: American Association of Petroleum Geologists Bulletin, v. 103, no. 3, p. 619-652.
Houseknecht, D.W., Lease, R.O., Schenk, C.J., Mercier, T.J., Rouse, W.A., Jarboe, P.J., Whidden, K.J., Garrity, C.P., Lewis, K.A., Heller, S.J., Craddock, W.H., Klett, T.R., Le, P.A., Smith, R.A., Tennyson, M.E., Gaswirth, S.B., Woodall, C.A., Brownfield, M.E., Leathers-Miller, H.M., and Finn, T.M., 2017, Assessment of undiscovered oil and gas resources in the Cretaceous Nanushuk and Torok Formations, Alaska North Slope, and summary of resource potential of the National Petroleum Reserve in Alaska, 2017: U.S. Geological Survey Fact Sheet 2017-3088, 4 p., accessed December 16, 2019, at https://doi.org/10.3133/fs20173088.

Wang, Y., Peters, K.E., Moldowan, J.M., Bird, K.J., and Magoon, L.B., 2014, Cracking, mixing, and geochemical correlation of crude oils, North Slope, Alaska: American Association of Petroleum Geologists Bulletin, v. 98, no. 6, p. $1235-1267$.

\section{For More Information}

Assessment results are also available at the USGS Energy Resources Program website at https://energy.usgs.gov.

\section{Central North Slope Assessment Team}

David W. Houseknecht, Katherine J. Whidden, Christopher D. Connors, Richard O. Lease, Christopher J. Schenk, Tracey J. Mercier, William A. Rouse, Palma J. Botterell, Rebecca A. Smith, Margaret M. Sanders, William H. Craddock, Christina A. DeVera, Christopher P. Garrity, Marc L. Buursink, Cevat O. Karacan, Samuel J. Heller, Thomas E. Moore, Julie A. Dumoulin, Marilyn E. Tennyson, Katherine L. French, Cheryl A. Woodall, Ronald M. Drake II, Kristen R. Marra, Thomas M. Finn, Scott A. Kinney, and Chilisa M. Shorten 